\title{
STUDY FOR IMPROVING THE EFFICIENCY OF PUBLIC FACILITIES MANAGEMENT: DETERMINING THE CURRENT STATE OF A MUNICIPALITY USING PUBLICLY AVAILABLE INFORMATION 公共施設マネジメントの効率化のための研究；公開情報を用いた地方自治体の現況確認手法
}

\author{
Sangjun $Y^{* 1}$, Kenji HIRAI ${ }^{* 2}$, Hiroki TSUTSUMI*3 \\ and Yukio KOMATSU*4 \\ 李＼cjkstart祥＼cjkstart準，平井健 嗣，堤＼cjkstart洋 樹，小松幸夫
}

\begin{abstract}
In an age of high economic growth, Japan constructed considerable infrastructure and public facilities without sufficiently considering management. These public facilities have deteriorated over several decades and they are in need of efficient management. However, owing to several problems, such as financial condition and insufficient information regarding the facilities, it is difficult to maintain these facilities efficiently.

This study proposes a method that can be applied to such investigation in most municipalities and describe their fiscal status and maintenance situation. We used radar charts and the PPM matrix to conduct this investigation.

The result of this study presents a method of understanding the general current state of a municipality, using publicly available information, and it proposes a technique that can define the problem.
\end{abstract}

Keywords: public facilities, financial reports, municipality, management, maintenance 公共施設，財政記録，地方自治体，マネジメント，維持保全

\section{Introduction}

1.1 Background and Purpose

In its age of great economic growth, particularly after the 1950s, Japan constructed an enormous amount of infrastructure and many public facilities without sufficient consideration for their management. As a result, Japan faces problems with public facilities on a huge scale, as the large number of facilities have increasingly aged and deteriorated over the decades. These facilities need repair or renovation, but their maintenance is not proceeding well due to budgetary concerns and insufficient data for management. Making this worse is the fact that the fiscal status is expected worsen as an aging society supplies lower tax income. Therefore, the first priority is to understand the state of the finances and public facilities in municipalities in order to clearly formulate a public facilities management plan. To investigate the fiscal status and the maintenance situation, it is important to collect information related to the running of the administration and the management of facilities in target municipalities from the past to the present. Most municipalities, however, cannot accomplish this due to a lack of data on the facilities. Moreover, such an investigation would require a considerable amount of time and expense. Therefore, this study proposes a simple method that can be applied to such investigation in most municipalities and that can describe their fiscal status, and maintenance situation.

\section{Scope and Method}

This study is based on the premise that a convenient and cost-effective analysis of the current situation of municipal bodies in Japan can substantially contribute to the development of a management plan for communal facilities.

Such an analysis should cover the following aspects related to a municipality:

(1) Publicly available information about the municipality

(2) Its financial health

(3) State of physical deterioration of the municipality's facilities

(4) Current maintenance plans for such facilities

*1 R. A., Dept. of Architecture, Faculty of Sci. and Eng., WASEDA Univ.

*2 Graduate Student, WASEDA University, M. Eng.

* 3 Assoc. Prof., Dept. of Architecture, MAEBASHI Inst. of Technology, Dr. Eng.

* 4 Prof., Dept. of Architecture, Faculty of Sci. and Eng., WASEDA Univ., Dr. Eng.

早稻田大学理工学術院創造理工学部建築学科 助手.丁修 早稲田大学大学院創造理工学研究科 博士課程·修士 (工学) 前橋工科大学建築学科 准教授. 博士 (工学)

早稲田大学理工学術院創造理工学部建築学科 教授・工博 
Data on the financial assets of the municipalities are available on the pages of their websites in the form of balance sheets, administrative cost statements, white papers, and statement of accounts. The investigations undertaken in this study are based on these freely accessible data sources, released annually by the municipalities on the Internet. A key advantage of using these sources is that the information is presented in the standard format prescribed by the Ministry of Internal Affairs, which allows for a comparison between municipalities. An integrated evaluation of various factors that which satisfy the required 3 condition(2),(3),(4)), extracted from the publicly available information, has been used in this study.

Target municipalities were selected from among the members of the public facilities stock management study group (26 municipalities in the Tama area of Tokyo). Municipalities that do not provide freely accessible data or use different formats were excluded. We collected data for the year 2006 because there was a high level of disclosure in that year.

Our method of analysis consisted of the following three stages.

1) Item selection and comparative analysis on the basis of data extracted from financial reports.

2) PPM matrix $^{* 1)}$ analysis for important items.

3) Creation of a scorecard showing the current state of a municipality on the basis of an integrated evaluation of various items.

\section{Analysis of Financial Reports}

In this section, I use the publicly available online fiscal information to evaluate the financial health of the municipalities, the level of deterioration of the municipality's facilities, and the measures adopted for the upkeep of these facilities. The analysis consists of the following three stages:

Stages 1: A simple comparative analysis using a single factor to identify the scope of operations and the present situation of the target municipalities

Stages 2: Comparative analysis of a combination of several factors, discussed in Section 3.1, with the help of the PPM matrix for clarifying the status of the target municipalities

Stages 3: Integrated evaluation of various factors to systematically determine the municipality's finances as well as the deterioration and the maintenance of the municipality's facilities

\subsection{Analysis item selection}

The objectives of this section are to identify the size and standing of each municipality by means of a single-factor comparison and to select the factors to be investigated in the "3.3 Integrated Evaluation".

Fig.1 shows the total tangible fixed assets (TFA) and population, which show the scale of the municipality. The scale of the total TFA for a populous municipality naturally tends to be larger, although the total TFA of Q, B, and C is larger than their population scale.

\section{1) TFA and liability per person}

TFA and liability are different depending on the scale of a municipality. To make a comparison between municipalities, one must understand the following: How many TFA has the municipality acquired to date? And how much liability is there now? These data were then converted into the value per person, giving the results shown in Fig.2.

The tendency in Figure 2 differs from that in Figure 1 and the TFA per person in municipalities $\mathrm{Q}, \mathrm{R}, \mathrm{B}$, and $\mathrm{F}$ are much larger. It is understood that the TFA per person in the three highest-ranking groups is three or more times that in the three lowest-ranking groups. In addition, there is not great difference in the liability per person, even though the TFA per person varies greatly. For example, municipality Q has the largest TFA per person, yet it has a small the liability per person. The reason for this is that a great deal of land was obtained from the former Japan Housing Corporation (presently UR) free of charge for new town construction. In municipality $\mathrm{R}$, despite the small scale, the liability (exceeding about 550,000 yen) and TFA (1.8 million yen)

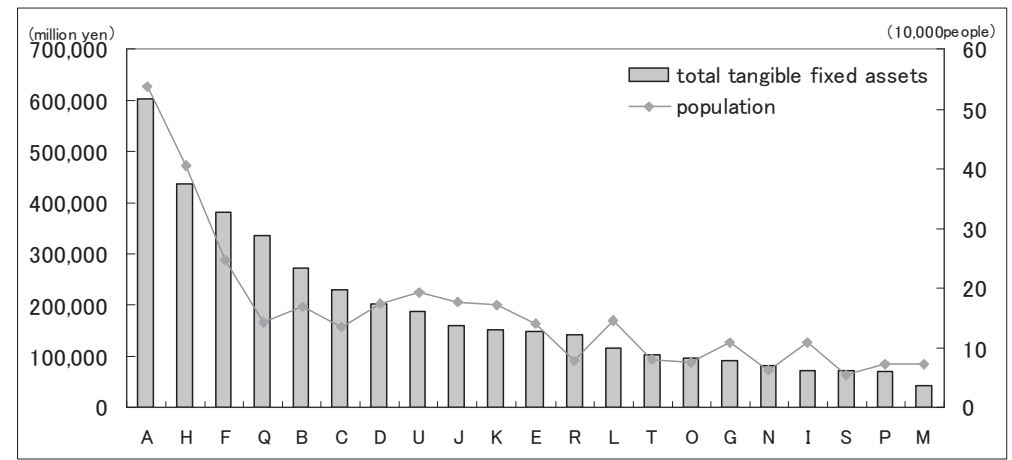

Fig.1 Total tangible fixed assets and population

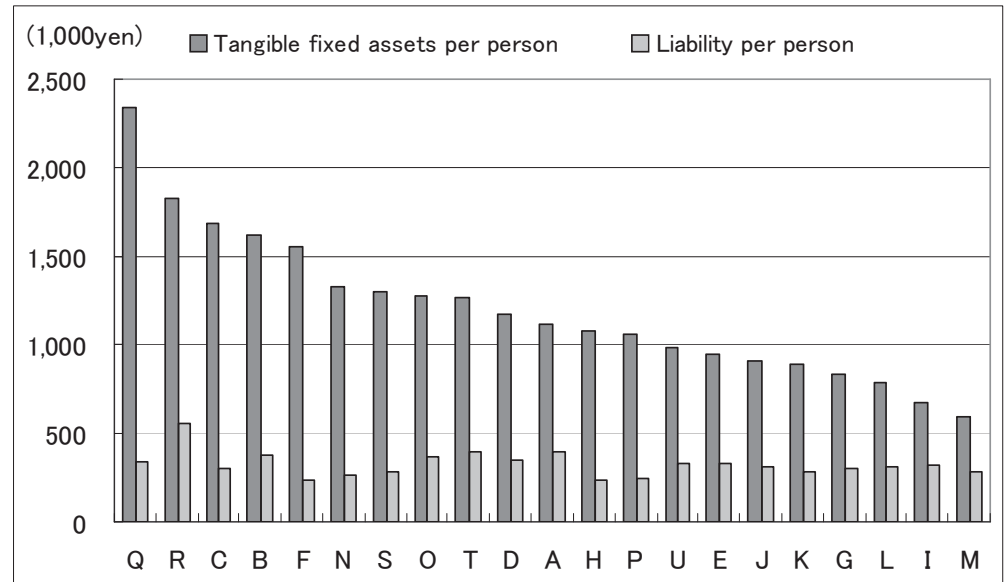

Fig. 2 Tangible fixed assets and liability per person 
per person are the largest.

2) Next Generation Load Ratio ${ }^{* 2)}$

Liability represents $\operatorname{debt}($ Liability= total assets - net worth $)$. It is the next generation that must shoulder the load of repayment. The next generation load ratio is the liability proportion of the TFA that the next generation must repay. According to Fig. 3, a liability of about $15 \%$ remains in the TFAs of municipalities $F$ and Q- this is the lowest value in our investigation. By contrast, municipality $\mathrm{M}$ has a liability of about $50 \%$. In other words, because about half the TFA is debt in municipality M, the next generation's load is large.

\section{3) Deterioration Ratio ${ }^{* 3)}$}

It is necessary to diagnose each facility's state of deterioration in order to understand the impact on the TFA. But, this is difficult to accomplish, due to the time and expense required. Here, a method for calculating depreciation is proposed for generally evaluating the extent of the impact of deterioration on a municipality's TFA. Briefly, the TFA can be estimated by assuming that it is diminished over time until the end of service life. But because land does not deteriorate, it is excluded in the TFA calculations here. On the balance sheet, depreciation is calculated by the straight-line method. This method, however, cannot reflect any improvements made by renovation.

Fig. 4 shows the deterioration rate for each municipality. Municipality $\mathrm{R}$, with a deterioration rate of $32 \%$, has the newest TFA. However, most of the other municipalities show a deterioration rate of about $50 \%$. Because this exceeds half the service life, seen overall, the TFAs are old and the maintenance load is large.

\section{4) Capital Allowance Ratio ${ }^{* 4)}$}

The capital allowance ratio is a measure used to understand how much available capital that needed to recover depreciated facilities value does the municipality have?

The concept is as follows. The total of amount in which value is lost by depreciation is called Accumulated Depreciation. The same amount as the depreciated amount costs to recover this. What percentage of this cost can be covered in the present fiscal status of

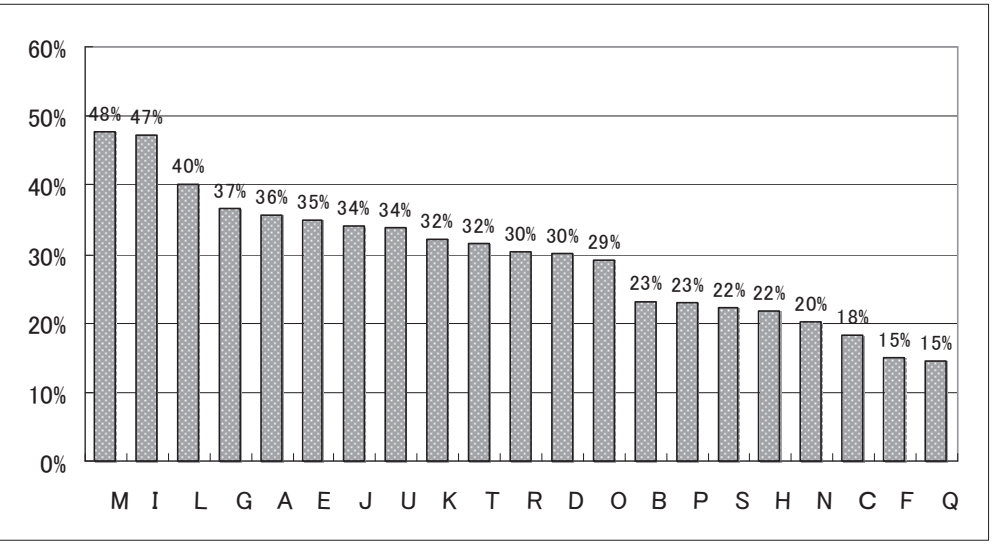

Fig. 3 Next Generation Load Ratio

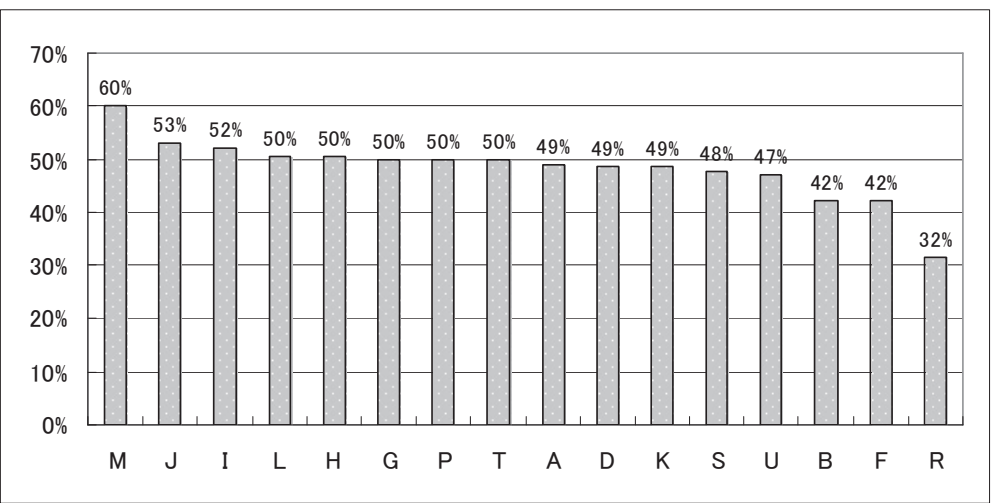

Fig. 4 Deterioration Ratio

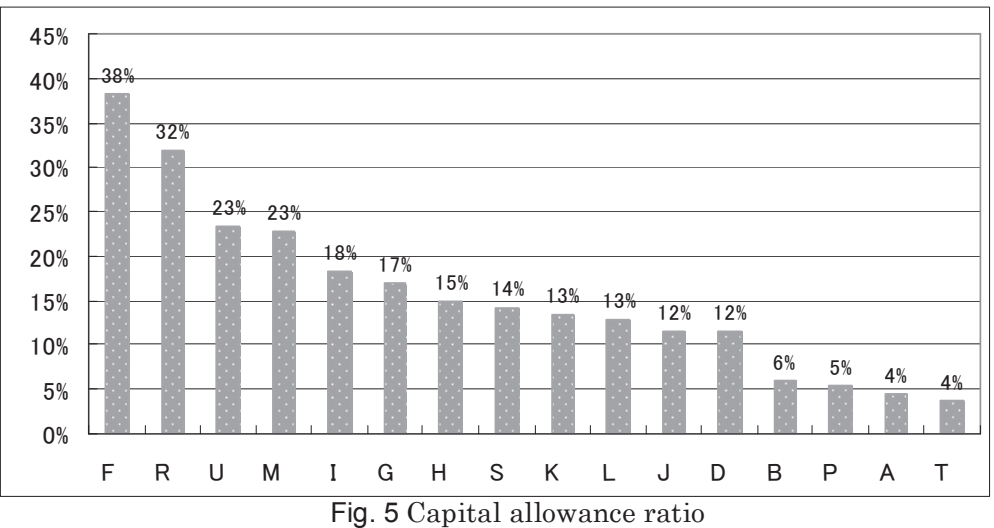
the municipality? In a word, to repair their own deteriorated facilities, have the municipality sufficient capital?

The capital allowance ratio for municipalities $\mathrm{F}$ and $\mathrm{R}$ exceeds $30 \%$ (Figure 5), and so it can be said the facilities in these municipalities can be repaired more readily than can those in the others. On the other hand, the situation of municipalities B, P, A, and T become severer, because the capital allowance ratio is $10 \%$ or less. $10 \%$ means that only $10 \%$ of deteriorated facilities can be repaired. It is therefore necessary to adopt a government subsidy system along with various other approaches to improving the efficiency of facilities management.

\section{5) TFA maintenance cost per person ${ }^{* 5}$}

The TFA maintenance cost represents the expenditure necessary for a municipality to maintain its TFA for one year. This index shows how much cost each municipality is using for their facility management. This item is compiled by adding up the maintenance repair expense, depreciation expenses, and the expense of interest on the public debt. Depreciation expenses are not actual expenditures made as part of the maintenance cost. However, it is assumed that an 
amount of money equal to the value of the drop in assets was saved for maintenance, and this is summed up as a maintenance cost. Because the expense of interest on the public debt is an interest cost generated when the public debt was issued for the funding the TFA, it is summed up as a maintenance cost. The proportion of the maintenance expense in the TFA maintenance cost per person is low. Also, no big difference among municipalities can be seen. Moreover, though the public debt interest is different among municipalities, it is not very different in respect to the amount of cost, except for the E municipality. Thus, it can be said that each municipality's actual expenditure on TFA maintenance is not very different from one municipality to another. However, the difference in the TFA maintenance cost is large because of the size of the depreciation amount. This means that it is difficult for this to correspond to the time of renewal and repair, though it is not actually spent as a maintenance cost.

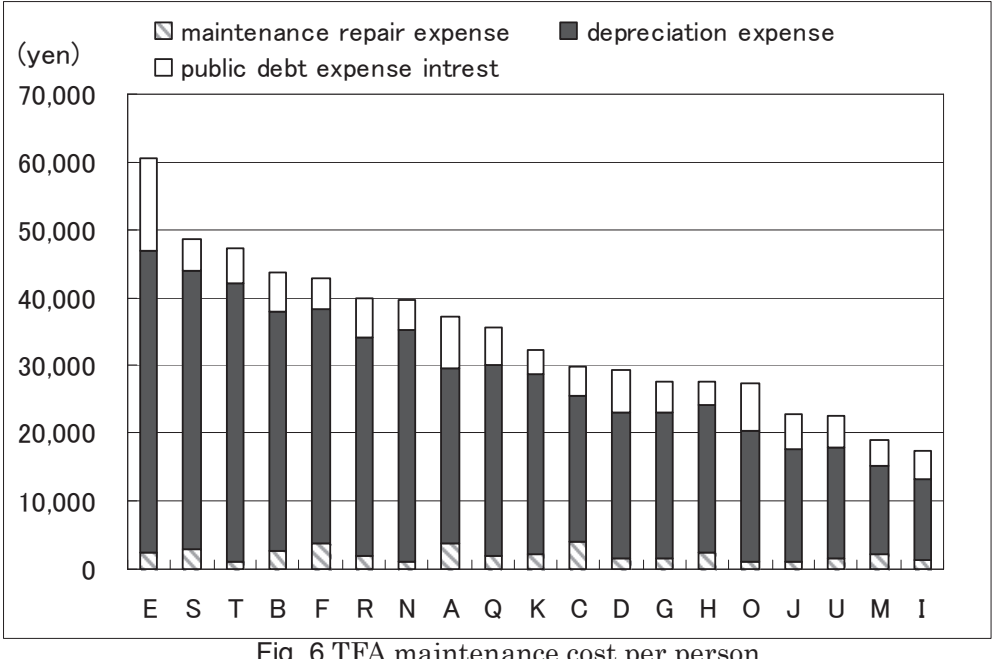

Fig. 6 TFA maintenance cost per person

\subsection{PPM Matrix Analysis}

In this chapter, evaluation is performed using the PPM matrix method with two axes based on the items presented in Section 3.1.

\section{1) Next Generation Load Ratio and TFA per person}

Here, Fig.7 presents a PPM matrix with the TFA per person (TFAP) on the X-axis and Next Generation Load Ratio (NGLR) on the Y-axis. If the figure is divided into 4 areas according to the average value of each axis, the right side of the matrix indicates having many TFAs and the upper side means having much debt. As can be seen in Fig.7, many municipalities are mostly in areas A and C. Area A is a case with high NGLR and few TFAP, and area $\mathrm{C}$ is a case with low NGLR and many TFAP. It is estimated that municipalities with higher tangible fixed assets (TFA) per person have nearly no outstanding payments, unlike those with fewer tangible fixed assets per person, which means that the next generation are supposed to be owed less debts in these municipalities.

2) Deterioration Ratio and Capital Allowance Ratio

Here, Fig. 8 presents a PPM matrix with the Capital Allowance Ratio (CAR) on the $\mathrm{X}$-axis and the Deterioration Ratio (DR) on the Y-axis. The right side of this matrix indicates a high capacity to respond to the demand for repair, and the upper side indicates many deteriorated facilities. Municipalities in area A are in the most serious condition, because area A is a case with a high DR and a low CAR. As can be seen in Fig.8, many municipalities are in area $\mathrm{A}$. Municipalities $\mathrm{R}$ and $\mathrm{F}$ in area $\mathrm{C}$ have new facilities and also have stable capital operations.

3) Deterioration Ratio and TFA maintenance cost per person Here, Fig.9 presents a PPM matrix with the Deterioration

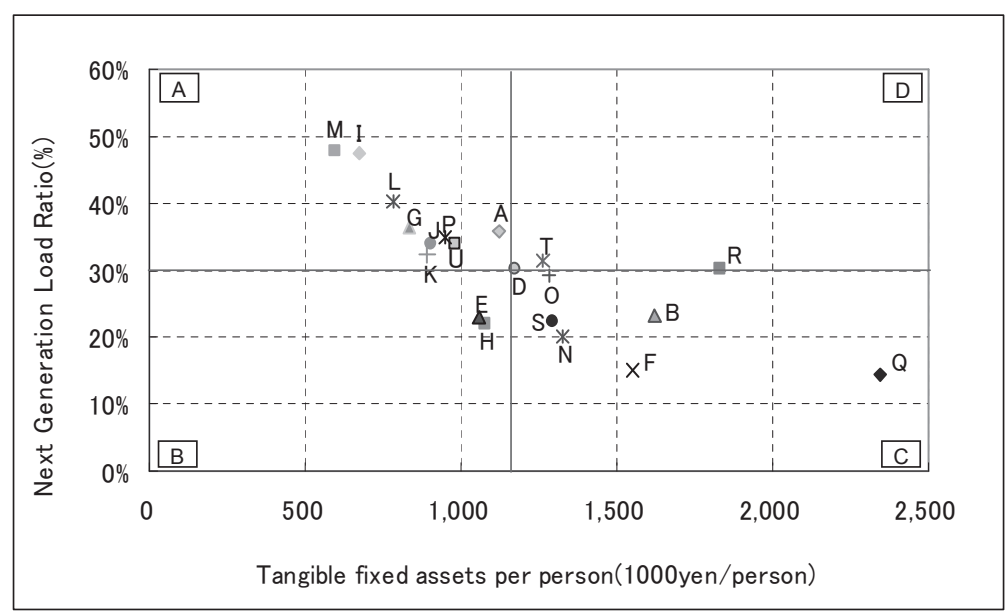

Fig. 7 Next Generation Load Ratio and TFA per person

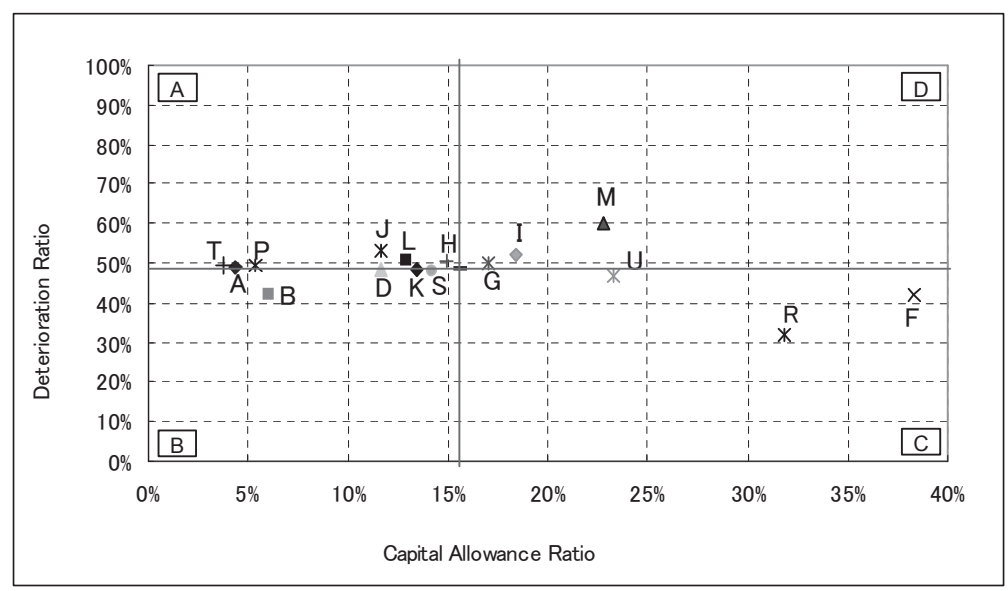

Fig. 8 Deterioration Ratio and Capital Allowance Ratio

Ratio (DR) on the X-axis and the TFA maintenance cost per person (TFAC) on the Y-axis. The facilities of the municipalities in area A are not in a comparatively advanced state of deterioration, so the costs incurred are for facility maintenance. The municipalities in area $\mathrm{C}$ are in the most serious condition 
because area $\mathrm{C}$ is a case with a high DR and low TFAC. It is estimated that facilities of the municipalities in area $\mathrm{C}$ are likely to deteriorate further in future owing to lack of funds for maintenance. This is because the TFA maintenance cost per person in this area is relatively low despite the poor physical condition of the facilities.

\subsection{Integrated Evaluation}

To understand a municipality's public facility maintenance situation, a variety of other items are reflected in the evaluation discussed in this section.

The flow of evaluation proceeds as follows.

(1) Item selection for analysis

(2) Scoring of each item

(3) Use of radar chart for integrated evaluation

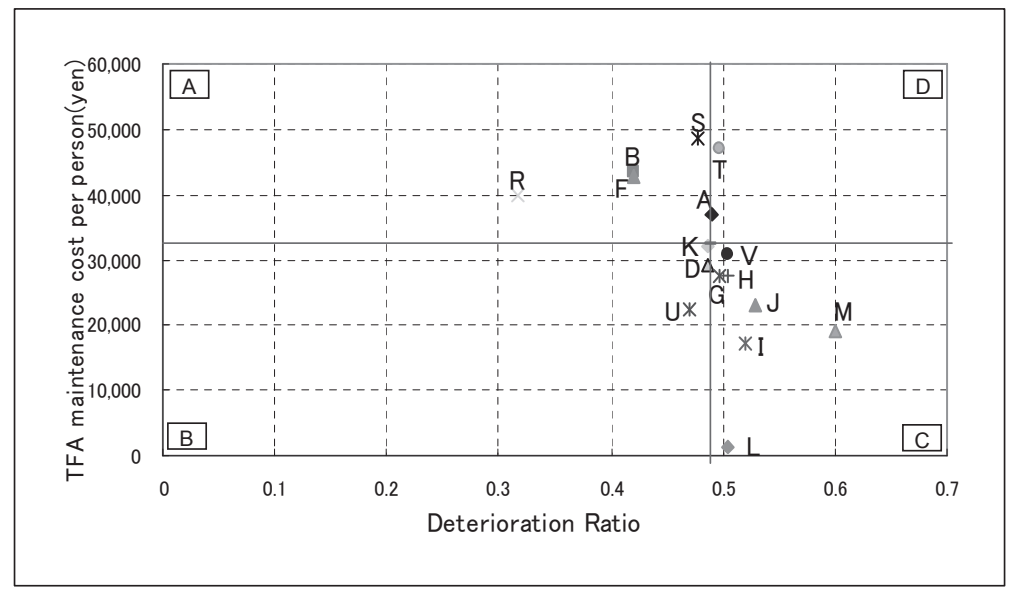

Fig. 9 Deterioration Ratio and TFA maintenance cost per person

1) Item selection for analysis

To examine the state of public facility maintenance implemented by the municipality, the following three indices were developed, in line with the requirements(2),(3),(4) identified in Section 2, and were used to generate an overall evaluation index.

1. "Index of the soundness of finances and management" which satisfy the required conditions

2. "Index of physical status of TFA" which satisfy the required conditions

3. "Index of corresponding activity for TFA management" which satisfy the required conditions

An evaluation plan comprising six items identified from the financial reports is shown in Table 1. To calculate the first index, items that reflect the fiscal status of the municipalities were selected: "next generation ratio," “capital allowance ratio," and "administrative cost vs. income item." "Next generation ratio" indicates the present liabilities of the municipality. "Capital allowance ratio" indicates the capital required by the target municipalities for carrying out maintenance operations for the deteriorated facilities. "Administrative cost vs. income items" indicates how much expenses are paid against the administrative outcomes from the incomes other than recurring general revenues.

The second index was calculated on the basis of the "deterioration ratio" identified from the publicly available information.

The third index indicates the cost to be allocated to the municipalities for maintenance of their facilities. This index was calculated on the basis of "cost that hangs TFA except land" and "repair cost per person." "Cost that hangs TFA except land" captures the annual expenses on TFA. It includes all types of construction cost, equipment cost, and cost of personnel employed for the operation and maintenance of the facilities. The item "repair cost per person" is calculated by adding the converted expenses to the cost per person.

Table 1 Items of analysis of various items

\begin{tabular}{ccc}
\hline Evaluation index & selected item & Index name \\
\hline \multirow{2}{*}{$\begin{array}{c}\text { Index that showed the Soundness of finance and } \\
\text { management }\end{array}$} & Capital Allowance Ratio & Net Worth degree \\
\cline { 2 - 3 } Index that showed a physical status of TFA & Administrative cost vs. income item & Administrative cost vs. Income degree \\
\hline Index that showed the correspondence activity & Cost that hangs to TFA except land & Cost degree that hangs to TFA except land \\
\cline { 2 - 3 } for the TFAM & Repair cost per person & Repair cost degree
\end{tabular}

2) Scoring of each item

To compare the six items with inconsistent units for inclusion on the radar chart, the standard deviation of each valuation selection item was used; this converts the index values into deviation values. The deviation value is found as follows.

$$
\text { Deviation value }=\frac{10 \times(\text { Value of municipality-average })}{\text { standard deviation }}+50
$$


Moreover, the calculation formula cannot be adopted as it is, because the smaller value is a better meaning in the NGLR and the DR. Therefore, the positive and negative of "Value of municipality-average" is reversed for these two items. Also, the requested evaluation value was assumed to be "Degree of Net Worth" and "Degree of Available Year." Other selection items also bear the names of the evaluation values in Table 1 for the deviation value. In addition, to perform an integrated evaluation, the "Public Facility Maintenance Status Evaluation Value" was derived from the average value of the deviation value of the six items.

3) Analysis by radar chart

A radar chart was used here to visualize the six items. Fig.10 shows the public facility maintenance status evaluation result for each municipality. The evaluation score for each evaluation item is given on a scale of 0 points to 80 points, with a value that approaches 80 points representing 'excellent'. The integrated evaluation score for Municipality F is 63.1, and it has well-balanced values for each of the six evaluation items. Municipality F has a sound financial and management status, and few deteriorated facilities. Therefore, a stable facilities management policy is possible, compared with what is possible for other municipalities. Municipalities I, J, M, and T had integrated evaluation scores of 50 points or less, and the balance of each evaluation item was lower than this. Municipality I and M had many deteriorated facilities and much debt. Also, because it is not efficiently used for maintenance even though the Degree of Capital Allowance Degree is comparatively high, it is thought that the situation in the municipality will become more severe. Municipality A is making efforts in the area of maintenance repair with few fiscal resources, which is compounded by a low degree of financial and managerial soundness and many old facilities. In fact, the staff of municipality A regularly voluntarily performs a simple diagnosis of the facilities deterioration, and is adopting a method of decreasing the number of construction orders.

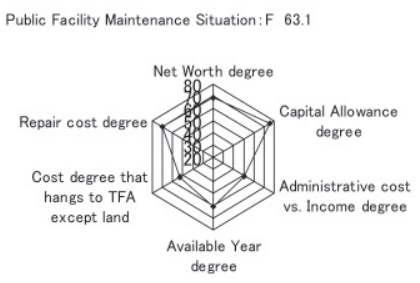

Public Facility Maintenance Situation:U 51.6

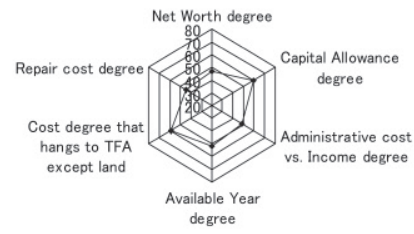

Public Facility Maintenance Situation: A 50.4

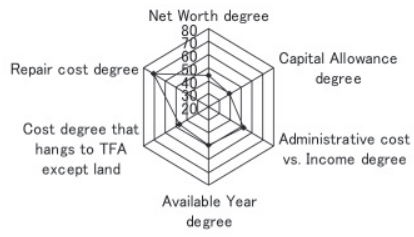

Public Facility Maintenance Situation: T 47.7

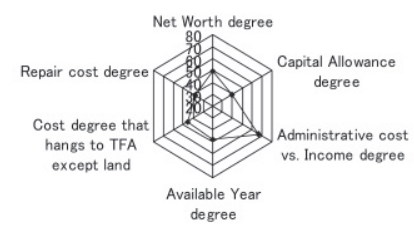

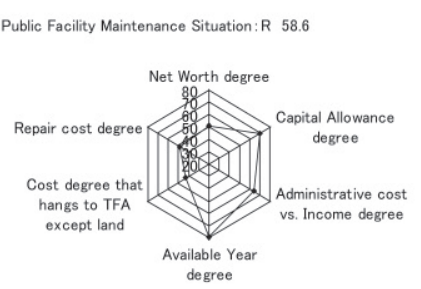

Public Facility Maintenance Situation:H 51.3

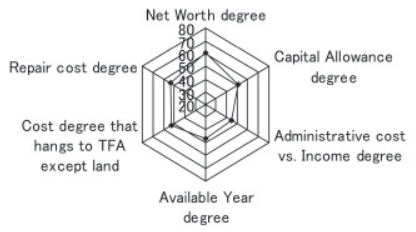

Public Facility Maintenance Situation: $\mathbf{G} 50.2$

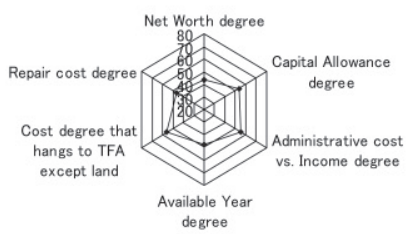

Public Facility Maintenance Situation:J 473

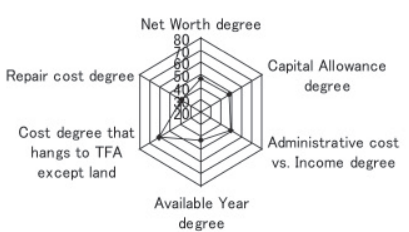

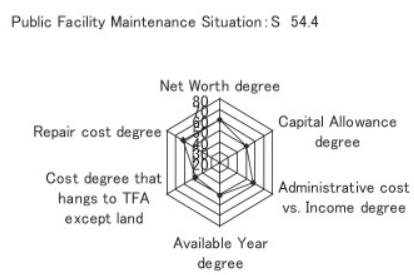

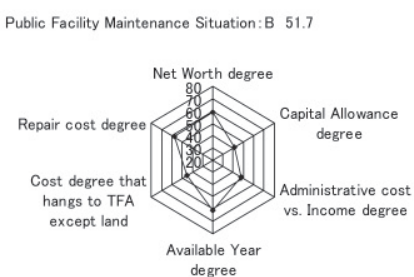

Public Facility Maintenance Situation:K 50.5

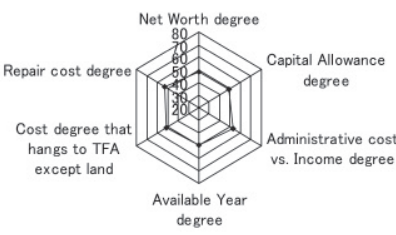

Public Facility Maintenance Situation:D 50.4

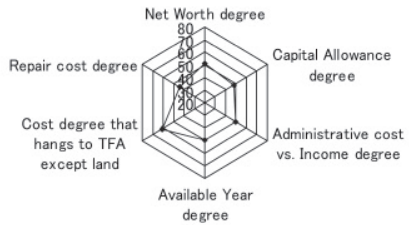

Public Facility Maintenance Situation:I 48.9
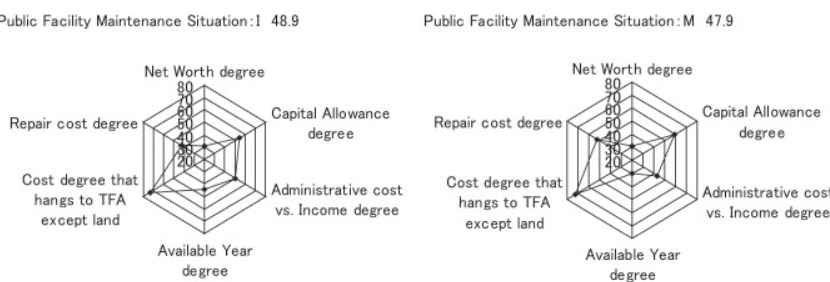

Fig. 10 public facilities maintenance situation evaluation of the municipality

\section{Conclusion}

To establish an efficient communal facilities management plan that is suitable for a municipality, it is important to ascertain the fiscal soundness, the extent of facility deterioration, and the maintenance situation of the municipality. In this study, I used publicly available fiscal information about the 
municipalities and analyzed it in three stages. The first stage involved a simple comparative analysis of a single factor, the second stage consisted of a comparative analysis of a combination of factors using the PPM matrix, and the third stage comprised an integrated evaluation of various factors. The third stage is especially useful in estimating the fiscal soundness, the extent of facility deterioration, and municipality maintenance. Such an evaluation can help a municipality understand the merits and demerits of its departments.

To summarize, this study presents a way to understand the general current state of a municipality using publicly available information, and it proposes a technique that can define the problem.

(1) It is thought that a municipality's scale of TFA is closely related to the settling down of the population in the region. It is considerably uneven to fiscal resources and the maintenance activity to correspond to it, though most of the Tama region's municipalities have a facilities deterioration rate of about 50 percent.

(2) According to the PPM matrix evaluation, the fiscal condition of a municipality with a lot of old facilities is much worse, and its facilities management has the possibility of becoming even more severe.

(3) In this study, three indices were developed to evaluate the situation of public facilities maintenance: index of financial health and soundness of management practice, index of physical condition of TFA, and index for TFA management practices. The usefulness of this method was verified by applying it to the study of municipalities in the Tama area. The results were successful in highlighting the merits and demerits of the municipalities in the area. In future, this method can be widely applied for investigating municipalities in other areas

\section{Acknowledgment}

This research has been supported by the Grant-in-Aid for Scientific Research(A) "Research on Establishing Public Facility Management System" under Grant No.20560594.

\section{Notes}

*1) PPM(Product Portfolio Management) is one of the evaluation techniques for using it when the decision making of the business strategy is done by effectively combining and managing two or more in corporate businesses. In this study, it tried to explain the facilities management state of the municipality by using the energy and water consumption and the facilities' use data.

*2) The Next Generation Load Ratio=Liability / Tangible Fixed Assets

*3) Deterioration Ratio = Accumulated Depreciation / Acquisition cost of TFA excluded land

The previously developed fiscal indices did not facilitate a comparison between municipalities because the indices of each municipality were computed differently. To remedy this situation, the "Research Group of Synthetic Fiscal Analysis of the Municipalities" within the Ministry of Home Affairs (currently, Ministry of Internal Affairs and Communications) proposed common guidelines for creating financial balance sheets (referred to as the "somusho method") in March 2000. In addition to adhering to these guidelines, many prefectures and municipalities also decided to publicly declare their financial information (balance sheets and administrative cost sheets). These guidelines mention that depreciation should be found with straight-line method so that the finances of municipalities can be compared as much as possible, by following the unified standard. This research has greatly benefited from this policy that requires municipalities to generate balance sheets and administrative cost calculation sheets by the "somusho method."

Referred from Gyousei : How to Make and Learn of Municipality Balance Sheet and Administrative Cost Statements, 2001

the Ministry of Home affairs : Report from the research group of the synthetic fiscal analysis of the municipalities, 2000

*4) Capital Allowance Ratio = Hand Capital /Accumulated Depreciation

*5) TFA maintenance cost per person $=($ maintenance repair expense + depreciation expenses + public debt expenses interest. $) /$ population

\section{References}

1) Gyousei : How to Make and Learn of Municipality Balance Sheet and Administrative Cost Statements, 2001

2) Mitsunari Ishida : Cost structure analysis of local public entity by corporate accounting technique, 2005

3) National Institute for Land and Infrastructure Management : NILIM Research Project Report, 2006.1

4) Sangjun YI and Yukio KOMATSU : A study on current situation of maintenance management in Public buildings, Proceeding of Annual Conference of the Architectural Institute of Korea 2007, pp.709-712, 2007.10

5) Tokyo City Construction Administration Conference Stock Management Study Group : Stock Management White Paper, 2008.5

6) JFMA : About The Facilities Property Strategy in the Municipality, 2008

7) Sangjun YI, Yukio KOMATSU, Kenji HIRAI and Hiroki TSUTSUMI : Investigation of Current State through Financial Report Analysis of the Municipalities, Conference of KICEM, Vol.9, pp.175-176, 2009.11

8) Sangiun YI and Yukio KOMATSU : Investigation of the Maintenance Condition in Public Facilities Focus on Comparison of the Municipalities in Tokyo, Journal of Asian Architecture and Building Engineering Vol.9 No.1，pp.125-130， 2010.5 


\section{和文要約}

地方自治体は日本の高度経済成長とともに膨大な公共施設を保有 することになる。その施設は今、老朽化による更新時期を迎えてい るが、地方自治体はこれに対応寸る準備ができていない。さらに経 済成長率鈍化や少子高齢化などの現状から地方財政は今後ますます 厳しくなる可能性が高い。そこで地方自治体の施設マネジメントプ ランを樹立が求められるが、まず財政・施設劣化・維持保全現状を
把握することが重要であるこのような状況を踏まえて本研究では、 公開情報を用いた地方自治体の現況を把握できる手法を提案する。 評価にはレーダーチャートと PPM マトリクスを活用した。本手法を 活用寸ることで地方自治体の財政状況、保有施設の老朽化状況、自 治体の取組み状況を短時間で概略的に把握することができると考え る。

(2010年11月10日原稿受理，2011年 3 月25日採用決定） 